\title{
Everolimus restrains the paracrine pro-osteoclast activity of breast cancer cells
}

\author{
Valeria Simone ${ }^{1 *}$, Sabino Ciavarella ${ }^{1}$, Oronzo Brunetti ${ }^{1}$, Annalisa Savonarola ${ }^{1}$, Mauro Cives ${ }^{1}$, Marco Tucci ${ }^{1}$, \\ Giuseppina Opinto ${ }^{2}$, Eugenio Maiorano ${ }^{2}$ and Franco Silvestris ${ }^{1}$
}

\begin{abstract}
Background: Breast cancer (BC) cells secrete soluble factors that accelerate osteoclast (OC) differentiation, leading to the formation of osteolytic bone metastases. In the BOLERO-2 trial, BC patients with bone involvement who received Everolimus had a delayed tumor progression in the skeleton as a result of direct $\mathrm{OC}$ suppression through the inhibition of mTOR, in addition to the general suppressor effect on the cancer cells. Here, we explored the effect of Everolimus, as mTOR inhibitor, on the pro-OC paracrine activity of BC cells.

Methods: Both MDA-MB-231 and MCF-7 BC cell lines were incubated with sub-lethal amounts of Everolimus, and their conditioned supernatants were assessed for their capacity to differentiate OCs from PBMC from healthy donors, as well as to interfere with their bone resorbing activity shown on calcium phosphate slices. We also measured the mRNA levels of major pro-OC factors in Everolimus-treated BC cells and their secreted levels by ELISA, and evaluated by immunoblotting the phosphorylation of transcription factors enrolled by pathways cooperating with the mTOR inhibition. Finally, the in vivo pro-OC activity of these cells was assessed in SCID mice after intra-tibial injections.
\end{abstract}

Results: We found that Everolimus significantly inhibited the differentiation of OCs and their in vitro bone-resorbing activity, and also found decreases of both mRNA and secreted pro-OC factors such as M-CSF, IL-6, and IL-1 $\beta$, whose lower ELISA levels paralleled the defective phosphorylation of NFkB pathway effectors. Moreover, when intra-tibially injected in SCID mice, Everolimus-treated BC cells produced smaller bone metastases than the untreated cells.

Conclusions: mTOR inhibition in BC cells leads to a suppression of their paracrine pro-OC activity by interfering with the NFkB pathway; this effect may also account for the delayed progression of bone metastatic disease observed in the BOLERO-2 trial.

Keywords: BOLERO-2 trial, Breast cancer cells, mTOR, Osteoclastogenesis, Everolimus

\section{Background}

The development of skeletal metastases, leading to hypercalcemia, fractures, and vertebral collapse with spinal compression and intractable pain, is a major cause of morbidity in patients with advanced breast cancer (BC) [1]. Their formation is primarily induced by a marrow environment fostering tumor growth, thanks to the functional cross-talk between $\mathrm{BC}$ cells and resident cells such as hematopoietic progenitors, stromal, endothelial and other marrow components [2]. Although a direct

\footnotetext{
* Correspondence: valeriasimo@gmail.com

'Department of Biomedical Sciences and Human Oncology, University of Bari "A. Moro", P.zza Giulio Cesare, 11-70124 Bari, Italy

Full list of author information is available at the end of the article
}

bone resorption activity by $\mathrm{BC}$ cells was postulated [3], it is currently believed that osteolytic lesions are produced by marrow osteoclasts (OC), whose differentiation from myeloid precursors is accelerated by the tumor cells [4]. BC cells secrete PTHrP (parathormone-related protein) [5], in addition to other soluble factors that are normally secreted by stromal and other marrow cells to regulate the OC maturation, and have M-CSF (macrophage-colony stimulating factor), IL (interleukin)- $1 \beta$, IL-8, IL-6 and TNF- $\alpha$ (tumor necrosis factor) functions [6-8].

Specific signatures of molecular pathways in $\mathrm{BC}$ cells have been associated with a highly malignant phenotype [9] and worse clinical outcome [10]. For instance, hyperactivity of the phosphoinositide 3-kinase (PI3K)/Protein 
Kinase B (Akt)/mammalian target of Rapamycin (mTOR) pathway, is a molecular hallmark of accelerated proliferation and tumor progression in $\mathrm{BC}$ cells, since intrinsic molecular aberrations recur in approximately $40 \%$ of patients with metastatic skeleton disease [11]. The constitutive phosphorylation of Akt, as well as mutations of the catalytic subunit of PI3K (PIK3CA), result in persistent activation of $\mathrm{mTOR}$ as the downstream serine/threonine kinase that primarily regulates proliferation, survival and apoptosis in $\mathrm{BC}$ cells [12]. Further work also suggests that this abnormal mTOR activity induces a peculiar osteotropic phenotype of $\mathrm{BC}$ cells, probably involved in skeleton colonization [13], that could ultimately be modulated by inhibiting this pathway, as demonstrated in other cancers [14].

Based on the results of the BOLERO-2 trial, the MTOR inhibitor Everolimus (RAD001) has been approved for use in postmenopausal women with hormone-receptor positive $\left(\mathrm{HR}^{+}\right) / \mathrm{Her}-2^{-}$advanced $\mathrm{BC}$, refractory to non-steroidal aromatase inhibitors [15]. In this study, a beneficial effect on bone health was documented in bone-metastatic patients receiving the drug, skeletal tumor progression being significantly delayed as compared to in the control group patients [16]. The bone resorption markers at 6 and 12 weeks revealed a significant decrease in patients treated with Everolimus [16], and this beneficial effect on bone health was attributed to the reduced OC function associated to the general anti-tumor activity induced by Everolimus on $\mathrm{BC}$ cells, as well as to a direct mTOR inhibition in $\mathrm{BC}$-stimulated OCs, since this pathway drives their functional maturation [17]. However, this result in the BOLERO-2 trial may also be explained as an effect of suppressed pro-OC paracrine activity of $\mathrm{BC}$ cells in response to the mTOR inhibition, besides its modulatory role on hyperactive OCs. Another trial, the RADAR study, suggested that Everolimus as a single agent was beneficial in patients showing only bone involvement [18]. These effects have been further emphasized in a recent subanalysis of the BOLERO-2 trial confirming the beneficial effect of Everolimus in the sub-population of $\mathrm{BC}$ patients with bone metastases, as well as in other subgroups [19].

However, in $\mathrm{OC}$ progenitors, as in $\mathrm{BC}$ cells, the secretion of pro-OC factors is independent of the mTOR pathway since the nuclear factor kappa B (NFkB) pathway is primarily involved through transcriptional factors regulating their release and activity [20-24]. Therefore, assuming that mTOR inhibition restrains the whole tumor activity in $\mathrm{BC}$ cells, as described in BOLERO-2, it is conceivable that both the mTOR and NFkB pathways may be molecularly interconnected and that their interaction may ultimately bring about the inhibitory effect on the secretion of pro-OC factors [25].

Here, we investigated the potential of Everolimus to regulate the pro-OC paracrine activity of $\mathrm{BC}$ cells, and provide evidence that this mTOR inhibitor restrains the bone-destroying potential of $\mathrm{BC}$ cells both in vitro and in vivo, through a synergic negative efficacy on both mTOR and NFkB. Thus, the NFkB-mediated suppression of the pro-OC paracrine activity by $\mathrm{BC}$ cells in patients enrolled in the BOLERO-2 trial may account for the beneficial bone effect attributed to Everolimus.

\section{Methods}

\section{Compound}

Everolimus [40-O-(2-hydroxyethyl)-rapamycin]) as pure extract powder was provided by Novartis Pharma and prepared in dymethylsulfoxide, diluted at $100 \mathrm{mg} / \mathrm{ml}$, for in vitro use.

\section{$B C$ cell lines and survival assay}

MDA-MB-231 and MCF-7 BC cells (ATCC, Rockville, MD, USA) were cultured in RPMI 1640 supplemented with $10 \%$ FCS (Sigma Aldrich, Milan Italy), $100 \mathrm{U} / \mathrm{ml}$ penicillin/streptomycin and $2 \mathrm{mM} \mathrm{L}$-glutamine (PAA, Pasching, Austria) in $5 \% \mathrm{CO}_{2}$-incubator. Both cell lines were incubated for $48 \mathrm{~h}$ with increasing concentrations $\left(10^{-1}\right.$ to $\left.10^{4} \mathrm{nM}\right)$ of Everolimus and their viability was assessed by methylene blue. Briefly, after fixation with glutharaldehyde, the cells were incubated for $10 \mathrm{~min}$ with methylene blue $[0.05 \%(w / v)$ in water], then treated with $\mathrm{HCl}[3 \%(v / v)]$ and read at $650 \mathrm{nM}$ of absorbance in a microtiter reader (BIO-Rad, Milan, Italy). The inhibitory concentration $20\left(\mathrm{IC}_{20}\right)$, defined as the amount of Everolimus able to reduce cell growth by $20 \%$, was calculated according to BioDataFit 1.02 software by interpolation of the dose-response curves. IC20 was arbitrarily used as the sub-lethal dose and each experiment was performed in triplicate.

\section{BC cell conditioned media (CM)}

After $48 \mathrm{hr}$-treatment with control DMSO or Everolimus at $\mathrm{IC}_{20}, \mathrm{BC}$ cells $\left(1 \times 10^{5} /\right.$ well $)$ were seeded in 6 -well plates for $24 \mathrm{~h}$. Then, supernatants were recovered, filtered, frozen at $-20^{\circ} \mathrm{C}$ until use for in vitro and in vivo experiments (see below).

\section{OC differentiation and activity}

Human OCs were obtained from the peripheral blood of healthy blood donors, after obtaining written informed consent, and approval by the Ethics Committee of the University of Bari. OCs were generated in vitro after 16day incubation of PBMCs with RANKL (50 ng/ml) and M-CSF (25 ng/ml) (Isokine, Iceland), as previously reported [26]. At day 8, PBMCs were supplemented with $20 \%$ of CM from DMSO- or Everolimus-treated cells and after a further 8 days of incubation, both the morphology and function of OCs were assessed. 
We arbitrarily considered as OC-like cells, polykaryons with at least three nuclei, that were counted in ten microscopic fields at 30× magnification after hematoxylin-eosin staining (Vector Labs, Sigma) and compared with tartrateresistant acid phosphatase positive $\left(\mathrm{TRAcP}^{+}\right)$cells in parallel preparations using naphthol AS-BI $0.12 \mathrm{mg} / \mathrm{ml}$, $6.76 \mathrm{mM}$ tartrate, and $0.14 \mathrm{mg} / \mathrm{ml}$ Fast Garnet $\mathrm{GBC}$ (Sigma-Aldrich).

Functional OC activity was measured on experimental bone substrate. Briefly, pre-OCs obtained after 8 days of culture in the presence of RANKL and M-CSF were incubated for a further 8 days with and without CM on calcium phosphate discs (BioCoat Osteologic Discs; BD Biosciences). Then, the cells were removed by $5 \%$ sodium hypochlorite and the substrates were stained by the Von Kossa method to reveal erosive pits. We also quantified both the number of pits and the percentage of the resorbed area by a dedicated software (Olympus) under light microscopy.

\section{RT-PCR}

After $48 \mathrm{hr}$-treatment with control DMSO or Everolimus at $\mathrm{IC}_{20}$, both the MDA-MB-231 and MCF-7 cell lines were measured for mRNA levels of $M-C S F, R A N K L$, TNF- $\alpha, I L 1-\beta, I L 6, M M P$ (metalloproteinase)-9, MMP13, MCP (monocyte chemoattractant protein)-1, MIP (macrophage inflammatory protein) $-1 \alpha$, as the major pro-OC factors [27-32]. Also, the OC-like phenotype of $\mathrm{BC}$ cells was assessed on the levels of TRAcP, cathepsin $K($ Cat $K)$ and $c$-fms. RNAs were extracted by the RNeasy kit (Qiagen, Chatsworth, CA) and the relative concentrations calculated by a Bio Photometer (Eppendorf) at $260 \mathrm{~nm}$. After evaluating RNA integrity by electrophoresis, cDNA was obtained by reverse transcription of $1 \mu \mathrm{g}$ of total RNA using a commercial kit (Applied Biosystems, Milan) in a Mastercycler Personal (Eppendorf). Levels of the above genes were assessed by specific primers (Additional file 1: Table S1) designed on different exons to avoid amplification of contaminating genomic DNA. $\beta$-actin was selected as target gene for the RT-PCR using Sybr Green (Maxima ${ }^{\circ}$ SYR Green/ROX qPCR Master Mix, Fermentas), in the ABI Prism 7300 Sequence Detector (Applied Biosystems). Following an initial incubation at $50{ }^{\circ} \mathrm{C}$ for $2 \mathrm{~min}$, samples were denatured at $95{ }^{\circ} \mathrm{C}$ for $10 \mathrm{~min}$, then by 40 cycles at $95{ }^{\circ} \mathrm{C}$ for $15 \mathrm{~s}$, and $1 \mathrm{~min}$ at $60{ }^{\circ} \mathrm{C}$. All tests were completed in triplicate and gene expression levels were obtained as $2^{-\Delta \Delta \mathrm{Ct}}$ [33].

\section{Measurement of pro-OC cytokines released by BC cells}

M-CSF, IL1- $\beta$, IL-6, TNF- $\alpha$ and MIP- $1 \alpha$ were measured in $\mathrm{CM}$ from each cell preparation by the appropriate ELISA (R\&D systems, Minneapolis, MN), as reported [34].

\section{Immunoblotting assessment of the mTOR and NFkB pathways in BC cells}

Both DMSO- and Everolimus-treated MDA-MB-231 and MCF-7 cells were investigated for activation of the mTOR and NFkB pathways, as well as for the production of NFkB-dependent pro-OC mediators. After $48 \mathrm{hr}-$ incubation, cells were harvested and lysed in mRIPA lysis buffer $(10 \mathrm{mM}$ Tris- $\mathrm{HCl}, 150 \mathrm{mM} \mathrm{NaCl}, 2 \mathrm{mM}$ EDTA, 1 \% NP40, 0.1 \% 0.1 \% SDS, 1 \% sodium deoxycholate) and $20 \mu \mathrm{g}$ of total protein lysate were resolved on $10 \%$ SDS-PAGE and subjected to Western-blotting [35] using MoAbs to Akt, phosphorylated (p)-mTOR, pp70S6K (Millipore, Billerica, MA, USA), IKK $\alpha, \mathrm{p}-\mathrm{IKK} \alpha$, p65, p-p65, as well as M-CSF, IL-1 $\beta$, IL-6 (Cell Signaling Technology, Danvers), TNF- $\alpha$ and MIP-1 $\alpha$ (Abcam, Cambridge). $\beta$-actin was used as intra-assay marker for both quality and quantity loading of sample lysates.

\section{Generation and detection of $\mathrm{BC}$ bone metastases in vivo}

To investigate the capability of $\mathrm{BC}$ cells to generate in vivo bone metastases and the effect of the $48 \mathrm{hr}$-treatment with sub-lethal doses of Everolimus, we utilized MDA-MB-231 as predominant bone metastasizing BC cell model [36] in 8-week old NOD.CB17-Prkdc ${ }^{\text {scid } / J}$ mice (Charles River, Milan, I). All experiments were performed in accordance with the Italian Guidelines for the use of laboratory animals, following the European Union Directive for the protection of experimental animals (2010/63/EU), after receiving approval from the Animal Experimentation Ethics Committee (CESA) of University of Bari "Aldo Moro". Animals were maintained under standard environmental conditions and provided with feed and water ad libitum. Considering the animal ethical issues, all animals were kept under best hygienic conditions and were daily inspected for signs of pain or discomfort. Briefly, eight mice were anesthetized by Isofluorane, and $1 \times 10^{5}$ cells $/ 20 \mu \mathrm{l}$ of Everolimus-treated and untreated MDA-MB-231 were inoculated into the left and the right tibial cavity, respectively, of the flexed knees of each animal. After 4 weeks, the animals were euthanized by carbon dioxide and X-Rays were taken at $20 \mathrm{kV}$ and $25 \mathrm{mAs}$ for $5 \mathrm{~s}$ using a mammographic device (Model Flat E; Metaltronica, Rome). Films were then comparatively inspected for structural deformities and the size of visible tibial lesions was measured by ImageJ software, version 1.45 (National Institutes of Health, Bethesda, MD). The extent of osteolytic areas, as $\mathrm{mm}^{2}$ of bone devastation, were compared in each mouse between the right and left tibias.

\section{Bone immunohistochemistry}

The tibias were excised, fixed and decalcified in EDTA for paraffin-embedding; $4 \mu$ m-thick sections were stained with hematoxylin-eosin while parallel sections 
were prepared for TRAcP staining (Aviva Systems Biology, San Diego) using specific reagents and avidin-biotin (Vector Labs, Burlingame) to reveal TRAcP ${ }^{+}$cells [37].

\section{Statistical analysis}

We employed GraphPad Prism 6.1 software (Macintosh, La Jolla, CA) and differences were calculated by Student's $t$ test. $P<0.05$ was considered statistically significant.

\section{Results}

\section{Everolimus sub-lethal dose}

We firstly assessed the cytotoxic activity of Everolimus on $\mathrm{BC}$ cells (Additional file 1: Figure $\mathrm{S} 1$ ). The $\mathrm{IC}_{20}$ concentration of Everolimus was $10 \mathrm{nM}$ for MDA-MB-231 cells and $0.5 \mathrm{nM}$ for MCF-7 cells; these were used as sub-lethal doses.

\section{$\mathrm{BC}$-induced osteoclastogenesis is restrained by Everolimus}

Figure 1a shows the pro-OC potential of CM from both $\mathrm{BC}$ cell lines, as untreated and Everolimus-treated cells. $\mathrm{CM}$ from both untreated cell lines produced higher numbers of polykaryons (MDA-MB-231: $32.5 \pm 1.5$; MCF-7: $45 \pm 6$ cells/field) compared to control PBMCs (16 \pm 1 cells/field; $p<0.05$ ), whereas CM from Everolimus-treated MDA-MB-231 and MCF-7 significantly reduced the polykaryon generation, to $35 \%(21 \pm 2.6$ cells/field $)$ and $23 \%$ (35 \pm 4 cells/field), respectively $(p<0.05)$. We further investigated the TRAcP expression in polykaryons (Fig. 1b). Again, the number of TRAcP ${ }^{+}$cells was enhanced by CM from both BC cell lines (MDA-MB-231: $35 \pm 2.5$; MCF-7: $43 \pm 2$ cells/field) as compared to control PBMC preparations $(22 \pm 2.5$ cells/field; $p<0.05)$, while this effect was neutralized by CM from both Everolimus-treated cell lines $(p<0.05)$. The bottom images of Fig. 1b illustrate basal TRAcP $^{+}$cell formation (left), after MCF-7 CM (middle), and $\mathrm{CM}$ from Everolimus-treated MCF-7 cells (right).

\section{Everolimus restrains the $\mathrm{BC}$-mediated $\mathrm{OC}$ hyperactivity}

The restraining effect of Everolimus on the pro-OC activity of $\mathrm{BC}$ cells was investigated at both RNA and functional levels.

As shown in Fig. 2, quantitative RT-PCR revealed that OCs had significantly increased mRNA levels of TRAcP, Cat- $K$ and $c$-fms after incubation with $C M$ from both the MDA-MB-231 and MCF-7 cell lines $(p<0.05)$. No variation was observed for RANK mRNA after adding MDA-MB-231 CM, whereas treatment with CM from Everolimus-treated $\mathrm{BC}$ cells resulted in a suppression of TRAcP, Cat-K and $c$-fms $(p<0.05)$. Functional tests supported these results. OCs showed a dramatically reinforced bone resorbing activity on calcium-phosphate slices after adding CM from both $\mathrm{BC}$ cell lines and, contrarily, a significantly inhibited activity when using $\mathrm{CM}$ from Everolimus-treated cells (Fig. 3). In particular, Fig. 3a (above) shows that OCs stimulated with CM produced higher numbers of erosion pits (MB-231: $45 \pm 2.5$; MCF-7: $32 \pm 3)$ than control OCs $(20 \pm 3.1)$, with increased total resorbed areas, equal to 3.8 and $3.1 \%$, respectively, with CM from untreated MDA-MB-231 and MCF7 cells, compared to $1.5 \%$ of the control OCs, as shown in Fig. 3a (below). By contrast, when using CM from Everolimus-treated $\mathrm{BC}$ cells, both erosion pits and resorbed areas were significantly reduced $(p<0.05$ in all instances). Figure $3 \mathrm{~b}$ depicts representative images of erosion pits on calcium-phosphate discs. These results emphasized the ability of Everolimus to restrain the BCmediated hyperactivity of OCs, at both molecular and functional levels.

\section{Everolimus restrains the pro-OC paracrine activity of $\mathrm{BC}$ cells}

MDA-MB-231 and MCF-7 were tested by RT-PCR for M-CSF, RANKL, TNF- $\alpha, I L-1 \beta, I L-6, M M P-9, M M P-13$, $M C P-1$ and $M I P-1 \alpha$, before and after Everolimus treatment. Levels of mRNAs were normalized to 1.0 as $2^{-\Delta \Delta c t}$ basal value and with the exception of RANKL, MMP-9 and $M C P-1 \alpha$, that were almost undetectable (data not shown), both cell lines showed a variably suppressed RNA transcription of the other genes after Everolimus treatment. Results are illustrated in Fig. 4a. MDA-MB231 cells underwent significant reductions $(p<0.02)$ of $M-C S F, T N F-\alpha$, and MMP-13 RNA levels whereas $I L-6$ was unaffected $(p>0.05)$, like $I L-1 \beta$ and $M I P-1 \alpha$. In parallel, MCF-7 cells were suppressed by Everolimus in $I L$ $1 \beta, I L-6, M I P-1 \alpha$ and $M M P-13$ ( $p<0.02$ in all instances), unlike $M-C S F$ and TNF $\alpha$.

To verify whether the suppressed transcription of RNAs was paralleled by a concurrent reduction in the secretion of related proteins, we measured M-CSF, TNF $\alpha$, IL-1 $\beta$, IL-6, MIP- $1 \alpha$, and MMP-13 amounts in $\mathrm{CM}$ by ELISA. Figure $4 \mathrm{~b}$ depicts the results, showing an apparent correlation of RNA amounts with lower secreted levels of those cytokines. MDA-MB-231 cells constitutively secreted consistent amounts of both M-CSF and TNF- $\alpha$, whereas MCF-7 cells produced higher levels of IL-1 $\beta$, IL-6 and MIP- $1 \alpha$ than MDA-MB-231. However, Everolimus significantly inhibited this paracrine activity in both cell lines ( $p<0.05$ in all instances).

\section{mTOR inhibition by Everolimus disables NFkB signaling in BC cells}

Since the NFkB pathway regulates the transcription of $M-C S F, I L-1 \beta, I L-6, T N F \alpha$ and $M I P-1 \alpha$ for the relative protein secretion by $B C$ cells, we investigated the interference exerted by Everolimus on mTOR and NFkB signaling. By Western-blot, we measured the amounts of major factors of both pathways, such as Akt, 

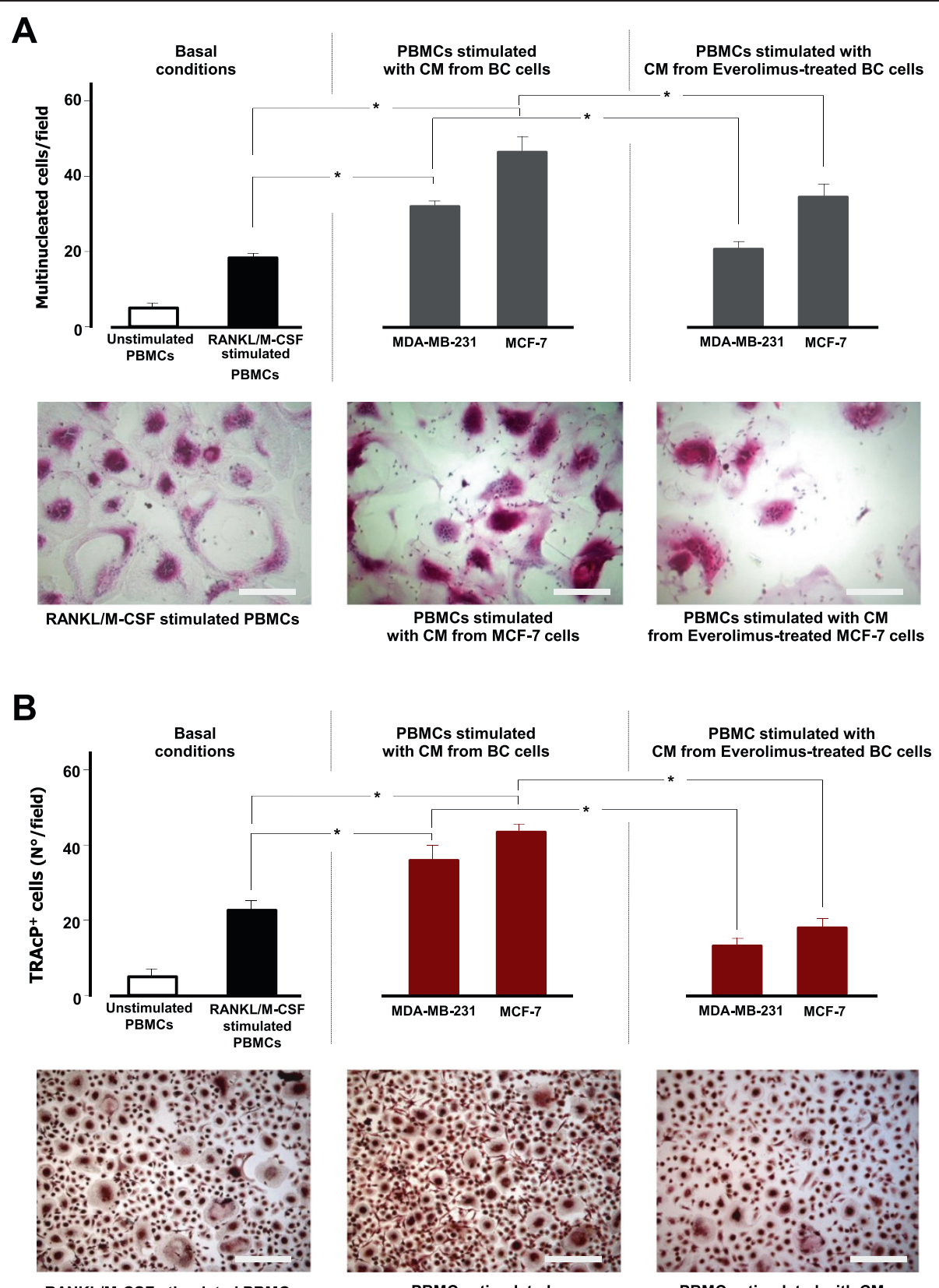

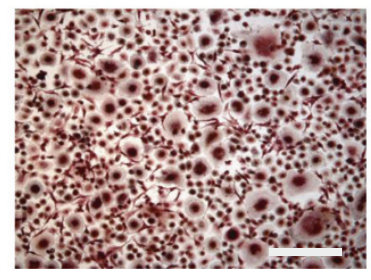

PBMCs stimulated with CM from MCF-7 cells

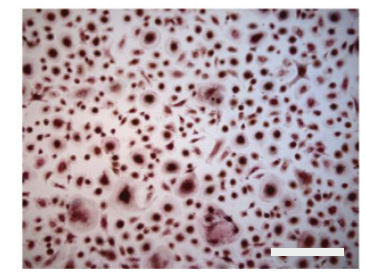

PBMCs stimulated with $\mathrm{CM}$ from Everolimus-treated MCF-7 cells

Fig. 1 Osteoclastogenic potential of BC cells and effects of Everolimus. PBMCs from healthy donors were differentiated to OCs using osteoclastogenic factors (left) and conditioned medium (CM) from MDA-MB-231 and MCF-7 BC cell lines, before (middle) and after (right) treatment with Everolimus. The pro-OC potential was measured as numbers of both large multinucleated OC-like cells stained by hematoxylin/eosin (a) and multinucleated TRACP ${ }^{+}$ cells $(\mathbf{b})$. CM from BC cells produced significant increases $\left({ }^{*} p<0.05\right)$ of OC formation, although the greatest effect was with MCF-7 cells (middle). Both constitutive and BC-mediated osteoclastogenesis were abrogated when using CM from BC cells pretreated with a sub-lethal dose of Everolimus. The pattern of increased/reduced OC formation was similarly evident after different staining. a bottom: Polykaryons from PBMCs cultured with RANKL/M-CSF (left), with CM from untreated (middle) and Everolimus-treated (right) MCF-7 cells (scale bar: 30 um; 30X magnification). b bottom: images of TRACP ${ }^{+}$OC-like cells (scale bar: $35 \mu \mathrm{m}$; 20x magnification)

phosphorylated (p) mTOR, p-p70S6K, IKKa, p-IKK $\alpha$, $\mathrm{p} 65$, and $\mathrm{p}-\mathrm{p} 65$, in both $\mathrm{BC}$ cell lines before and after Everolimus treatment. Figure 5 (up) depicts the constitutively increased expression of p-mTOR and its downstream effector p-p70S6K in both cell lines, although at higher levels in MCF-7 (OD values are in, Additional file 1: Table S2). As expected, Everolimus decreased pmTOR and p-p70S6K levels in both cell lines, particularly in MCF-7 cells, whereas no change in Akt expression was observed, confirming the ability 
RNA transcription levels

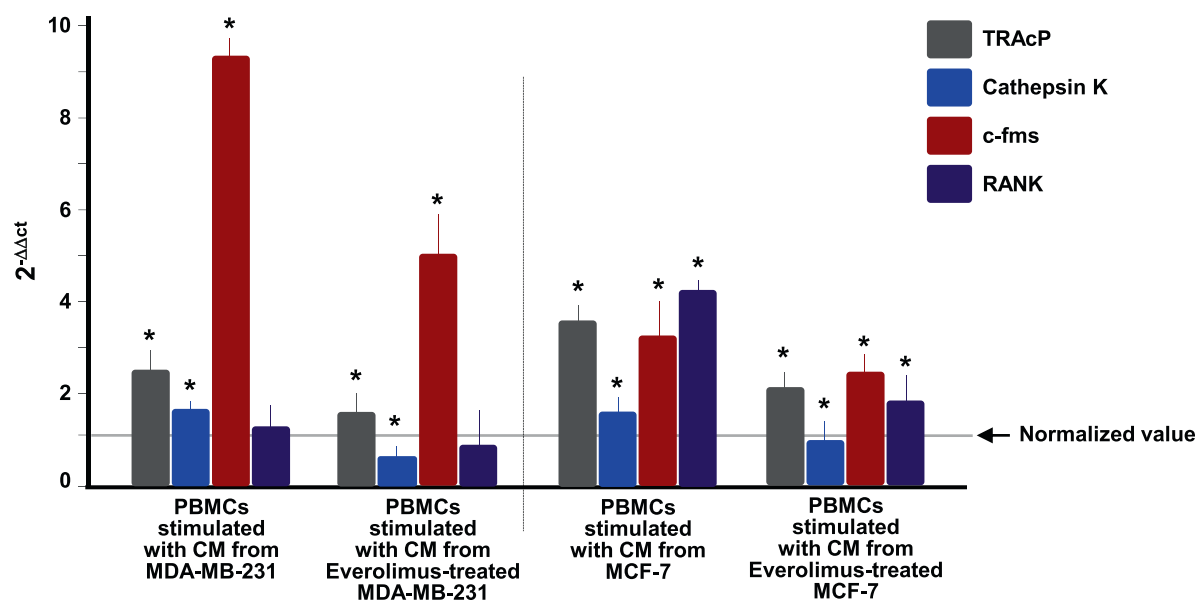

Fig. 2 Effect of BC cells on the transcription of OC genes in PBMCs and inhibition by Everolimus. RNA levels of TRACP, Cat-K, C-fms and RANK in PBMCs after incubation with CM from BC cells, before and after treatment with Everolimus. Transcripts were variably increased in both cell lines, particularly c-fms by MDA-MB-231, and significantly down-regulated by Everolimus. RNA levels were normalized to control OCs and to $\beta$-actin levels as house-keeping gene, and expressed as $2^{-\Delta \Delta C T}$

of Everolimus to selectively target the m-TOR molecule and hence inhibit the m-TOR-dependent p70S6K factor.

The inhibition of the interaction between the mTOR and NFkB pathways exerted by Everolimus is shown in Fig. 5 (middle) on both cell lines. IKK $\alpha$ and p65 exhibited variably inhibited phosphorylated forms after Everolimus. The effect was more pronounced for $\mathrm{p}-\mathrm{IKK} \alpha$ in MCF-7 cells, due to the higher constitutive expression of this factor. Similarly, M-CSF, IL-6, IL-1 $\beta$, TNF $\alpha$, and MIP- $1 \alpha$ were measured as NFkB-dependent factors. Figure 5 (below) shows their lowered intracellular content after Everolimus, especially in MCF-7 cells, supporting the hypothesized negative regulation of NFkB signaling by $\mathrm{m}$ TOR inhibition.

\section{Everolimus-treated MDA-MB-231 cells reveal a restrained osteolytic activity in SCID mice}

Everolimus-treated and untreated MDA-MB-231 cells were inoculated into the left and right tibia, respectively, of each 8-week old SCID mouse. After 4 weeks, X-Rays were taken to measure the extension of osteolytic areas. We observed smaller osteolytic areas in the tibias engrafted with treated MDA-MB-231 cells compared to the contralateral tibias, that uniformly showed variably enlarged proximal epiphyses due to the growth of metastatic lesions. Figure $6 \mathrm{a}$ (left) illustrates a representative X-Ray of a SCID mouse. As can be seen, the right tibia injected with untreated MDA-MB-231 produced a larger osteolytic lesion with blown cortical bone, compared to the smaller lesion produced by Everolimus-treated cells in the left tibia. Figure 6a (right) shows the average size of these osteolytic areas measured on X-Ray films of all mice, supporting the evidence of significantly larger lesions in the right tibias, injected with untreated MDAMB231 cells (mean value: $1.7 \pm 0.56 \mathrm{~mm}^{2}$ ) compared to the left tibias, injected with Everolimus-treated cells $\left(0.9 \pm 0.31 \mathrm{~mm}^{2}\right)(p<0.03)$. Finally, Fig. $6 \mathrm{~b}$ and $\mathrm{c}$ shows the histology pattern of tumor engraftment by MDAMB231 cells of the right tibia of a SCID mouse, displaying devastation of the bone structure, massive infiltration of the spongy bone, and a number of $\mathrm{TRAcP}^{+}$cells, so functional OCs, in close contact with the tumor cells and juxtaposed to the cortical bone.

\section{Discussion}

Endocrine therapy is the standard care for patients with advanced $\mathrm{HR}^{+} \mathrm{BC}$. However, after an initial response, most patients develop endocrine resistance. The underlying molecular mechanism is PI3K/Akt/mTOR hyperactivity, that drives the phosphorylation of the estrogen receptor (ER) by p70S6K, leading to a ligand-independent ER transcriptional activity. The involvement of mTOR in the cell growth of endocrine resistant BC cells is also supported by the convergence of signaling from different growth factor receptor pathways, such as the epidermal growth factor receptor (EGFR), insulin growth factor receptor (IGF-1R) and insulin receptor (InsR), toward PI3K/ Akt/mTOR [38]. Moreover, besides the expected improvement of progression-free survival obtained by mTOR inhibition in Everolimus-treated patients with endocrine resistant $\mathrm{BC}$, results from the BOLERO-2 trial suggest that this drug significantly delays skeletal disease progression, exerting a definite bone-sparing effect in metastatic BC patients [16].

Skeletal metastases occur in BC as an effect of the osteotropism of this tumor, that primes OC hyperactivity to 

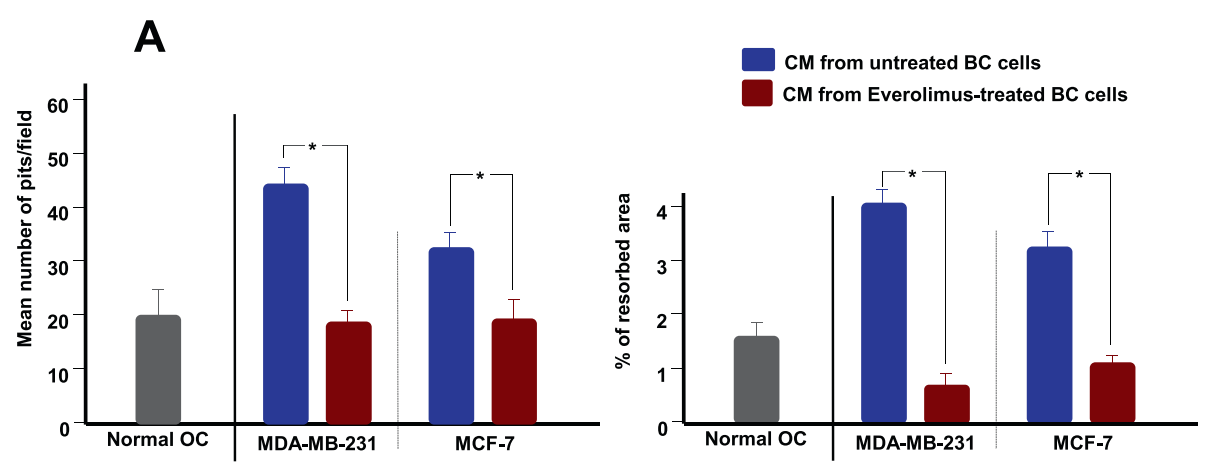

B
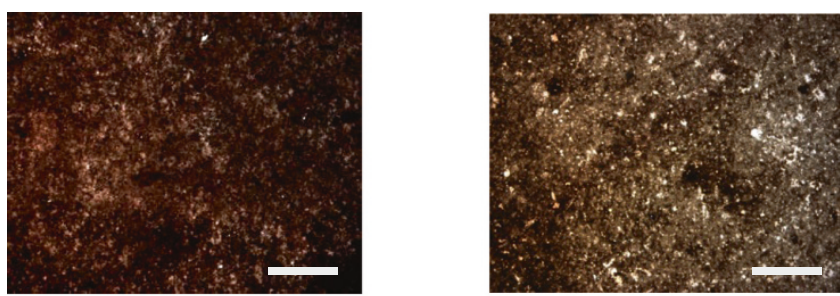

Control PBMCs

RANKL/M-CSF-
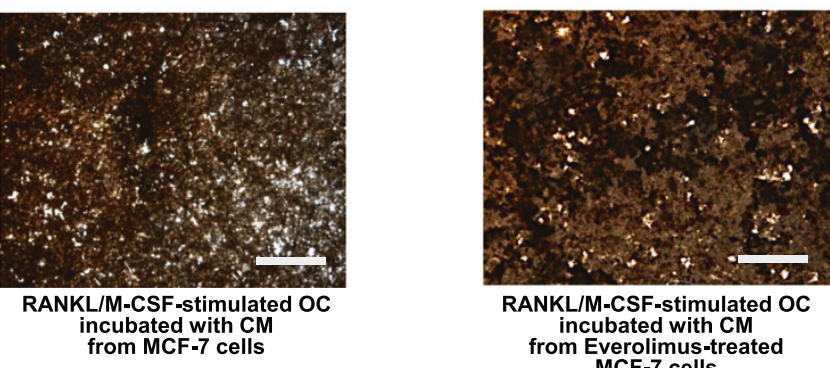

Fig. 3 Measurement of bone resorbing activity of OCs stimulated by BC cells. The OCs capacity to produce erosive lacunae on calcium phosphate was measured after stimulation with CM from both untreated and Everolimus-treated BC cells. a Significant increases of the number of erosion pits (above) and percentage of resorbed area (below), were observed after incubating OCs with CM from both BC cells, whereas this effect was significantly suppressed by Everolimus ( ${ }^{*} p<0.05$ ). Results are means of three experiments. $\mathbf{b}$ Variation of erosive pit formation by von Kossa-staining of calcium phosphate slices seeded with OCs compared to culture conditions. CM from Everolimus-treated MCF-7 cells inhibited the bone resorbing activity (bottom, right) compared to the constitutive activity (above, right) and to untreated cells CM (bottom, left) (scale bar: $25 \mu \mathrm{m}$; $40 \mathrm{x}$ magnification)

generate typical osteolytic lesions. Although BC cells themselves are suspected to degrade the bone matrix [3], their paracrine pro-OC activity is a major pathogenic event driving excessive OC differentiation and hyperactivation, resulting in the formation of bone metastases [39, 40]. Therefore, we investigated whether Everolimus acts as a negative regulator of the paracrine pro-OC activity of $\mathrm{BC}$ cells.

The beneficial effect of Everolimus on bone health in the BOLERO-2 study has also been interpreted as a result of the inhibition of mTOR activity in OCs $[16,17]$. It has been demonstrated in transgenic mice, bearing human-TNF $\alpha$ to resemble a rheumatoid arthritis model, that mTOR signaling drives OC function, and that inhibition of this pathway can mitigate bone erosion [41]. In these animals, mTOR inhibition by Everolimus or
Sirolimus resulted in a significantly decreased structural damage in joints.

We used the BC cell lines MDA-MB-231 and MCF-7, both capable of producing osteolytic lesions in animals $[36,42]$. In line with previous data [43], both cell lines secreted variable amounts of pro-OC factors and their $\mathrm{CM}$ accelerated the differentiation of PBMCs to $\mathrm{TRAcP}^{+}$ polykaryons, namely OCs showing bone-resorption activity in vitro, with a concurrent RNA increase of pivotal OC-related genes, such as RANK and $c$-fms as phenotype markers, and cathepsin- $K$ and $T R A c P$ as functional markers.

Everolimus treatment of $\mathrm{BC}$ cells inhibited the release of pro-OC factors. Using their CM, we observed a decline in the formation of $\mathrm{TRAcP}^{+}$polykaryons, together with a lower transcription of major $\mathrm{OC}$ factors and 

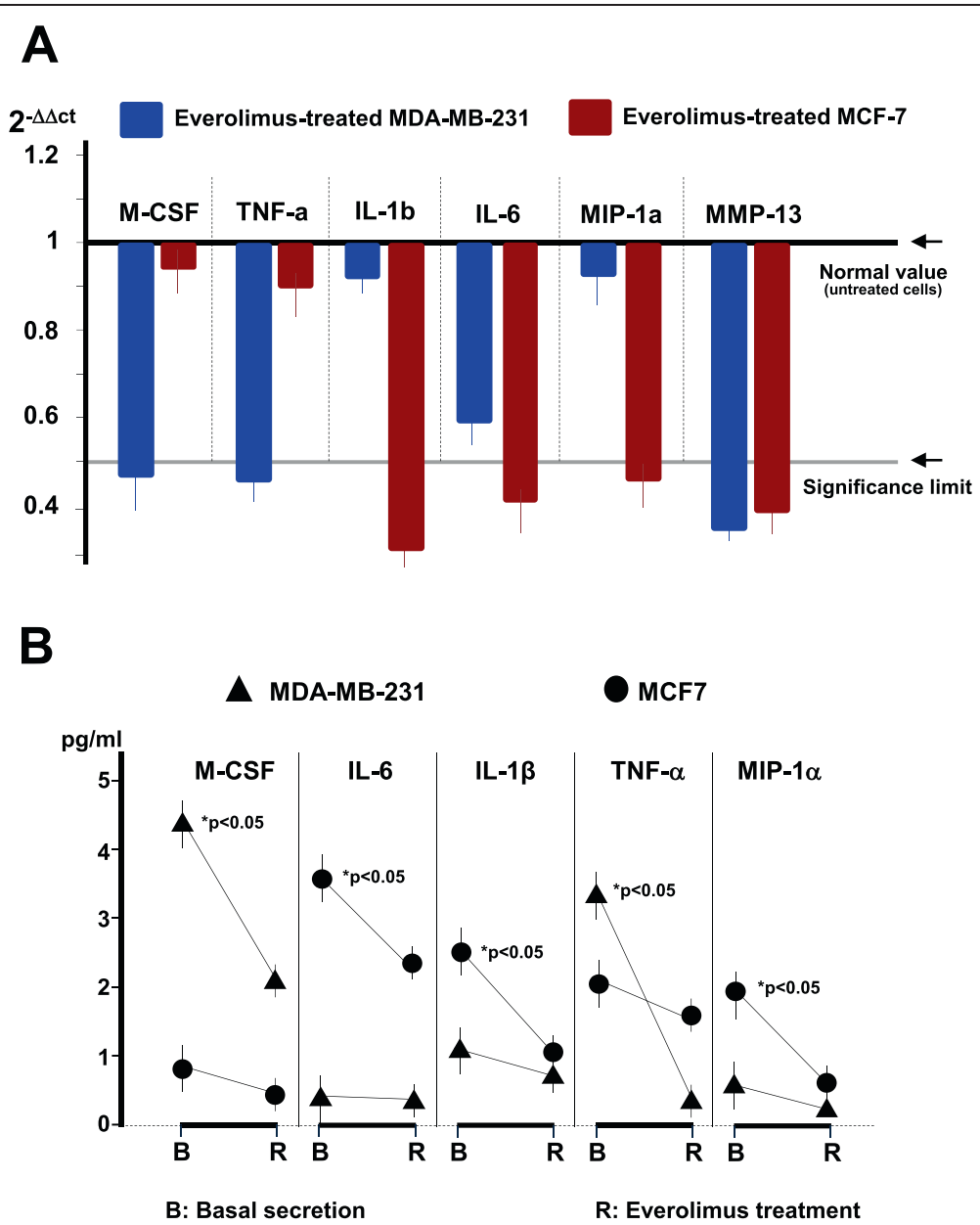

Fig. 4 Transcriptional and secretory profiles of pro-OC factors in Everolimus-treated BC cells. RNA levels of M-CSF, TNFa, IL- $\beta$, IL-6, MIP-1a and MMP-13 were variably suppressed in both MDA-MB-231 and MCF-7 cells after treatment with Everolimus. a RT-PCR showed a significant reduction of M-CSF, TNFa, and MMP-13 RNAs in MDA-MB-231, with a concurrent diminution of IL-6. IL-13, IL-6, MIP-1a and MMP13 were also significantly inhibited in MCF-7 cells as compared to normalized values from control untreated BC cells. Data are mean values from three experiments. $\mathbf{b}$ ELISA measurement of major NFkB-dependent osteoclastogenic factors, namely M-CSF, IL-6, IL-1ß, TNF- $a$ and MIP-1a, released by cultured MDA-MB-231 and MCF-7 cells before or after sub-lethal doses of Everolimus. In most instances, Everolimus suppressed the secretion of these factors (mean values from three experiments), showing a similar pattern to that of RNA inhibition

decreased bone resorbing ability. However, although these effects were similarly detectable in both cell lines, a higher inhibitory effect was recorded when PBMCs were stimulated with CM from Everolimus-treated MCF-7 cells. We interpreted this result as dependent on the higher sensitivity to Everolimus treatment of MCF-7 cells, as an effect of the intrinsic PIK3CA deregulation leading to a constitutive mTOR hyperactivity [44]. On the other hand, in both cell lines the RNA of $M-C S F$, $T N F \alpha, I L-1 \beta, I L-6, M I P-1 \alpha$ and $M M P-13$, as major proOC factors, was variably lowered by Everolimus: the basal transcriptional profile implying a well-defined inherited pro-OC potential was negatively regulated by the mTOR inhibitor. However, transcriptional levels of other genes such as RANK-L, $M C P-1$ and $M M P-9$ remained undetectable, as reported by other investigators [45].
A major result in our work was the inhibition of M-CSF, IL-6, IL- $1 \beta$, TNF $\alpha$ and MIP- $1 \alpha$ induced by mTOR inhibition. Constitutive phosphorylation of p70S6K, 4EBP1 and eIF4E, as downstream mTOR effectors [46], has been described to contribute to cell growth, angiogenesis and metastasis in several tumors. mTOR inhibition restrains these effects without having any apparent impact on MCSF, IL-6, and IL- $1 \beta$ secretion, since these factors are regulated by NFkB [20-24], whose activation is apparently independent of the mTOR pathway. This point is disputed, however, since previous works reported that a potential interaction between mTOR and IKK $\alpha$ triggers NFkB in tumor cells and constitutive activation of the $\mathrm{PI} 3 \mathrm{~K} / \mathrm{Akt} / \mathrm{mTOR}$ pathway $[25,47]$. We thus investigated whether NFkB signaling is affected by mTOR. After treatment of both cell lines with Everolimus, the secretion of 


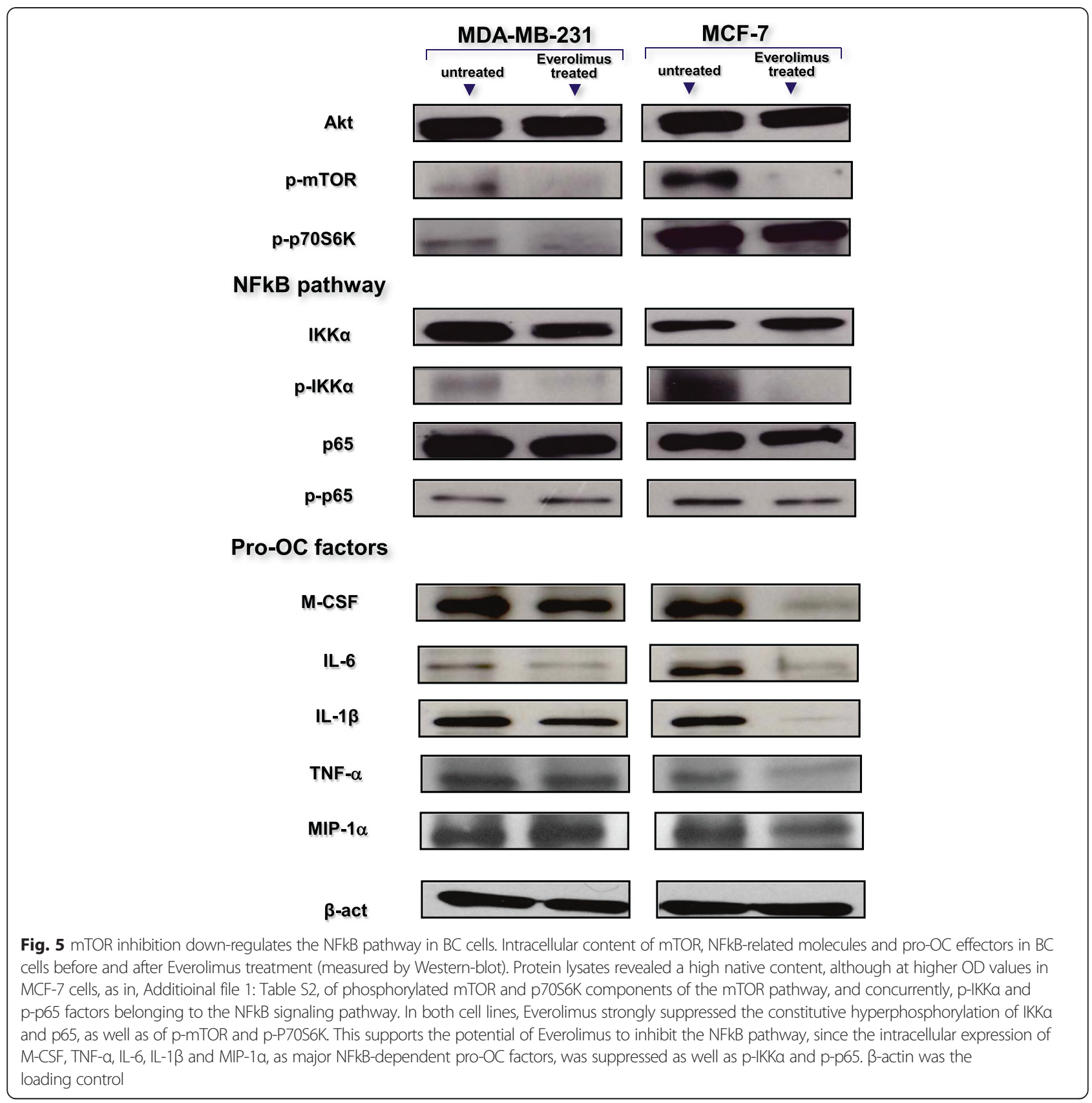

M-CSF, TNF $\alpha$, IL-1 $\beta$, IL- 6 and MIP- $1 \alpha$ in culture was significantly reduced, in parallel with lower RNA values. These data, together with the increased phosphorylated levels of pIKK $\alpha$ and p-p65 at immunoblotting, support a synergic down-regulation of both mTOR and NFkB. We found, indeed, that higher levels of Akt, p-mTOR and p-p70S6K in MCF-7 cells were correlated with similarly increased levels of p-IKK $\alpha$ and p-p65 along the NFkB pathway. The inhibition of NFkB phosphorylated effectors after treatment with Everolimus definitely suggests a functional connection between the mTOR and NFkB pathways.
It has been suggested that the functional disablement of NFkB following proteasome inhibition may affect intracellular signaling propagated through the mTOR pathway [48]. In our study, however, we provide inverse evidence that, at least in BC cells, both $\mathrm{p}-\mathrm{IKK} \alpha$ and $\mathrm{p}$ p65, as NFkB components, can be disabled by inhibiting mTOR. Although it has been reported that both MDAMB-231 and MCF7 may acquire resistance to everolimus [49], in our hands, the minor intracellular content of pro-OC factors, namely M-CSF, IL-6, IL-1 $\beta$, TNF $\alpha$ and MIP-1 $\alpha$, induced by NFkB in Everolimus-treated BC cells emphasizes the interactive negative regulation 

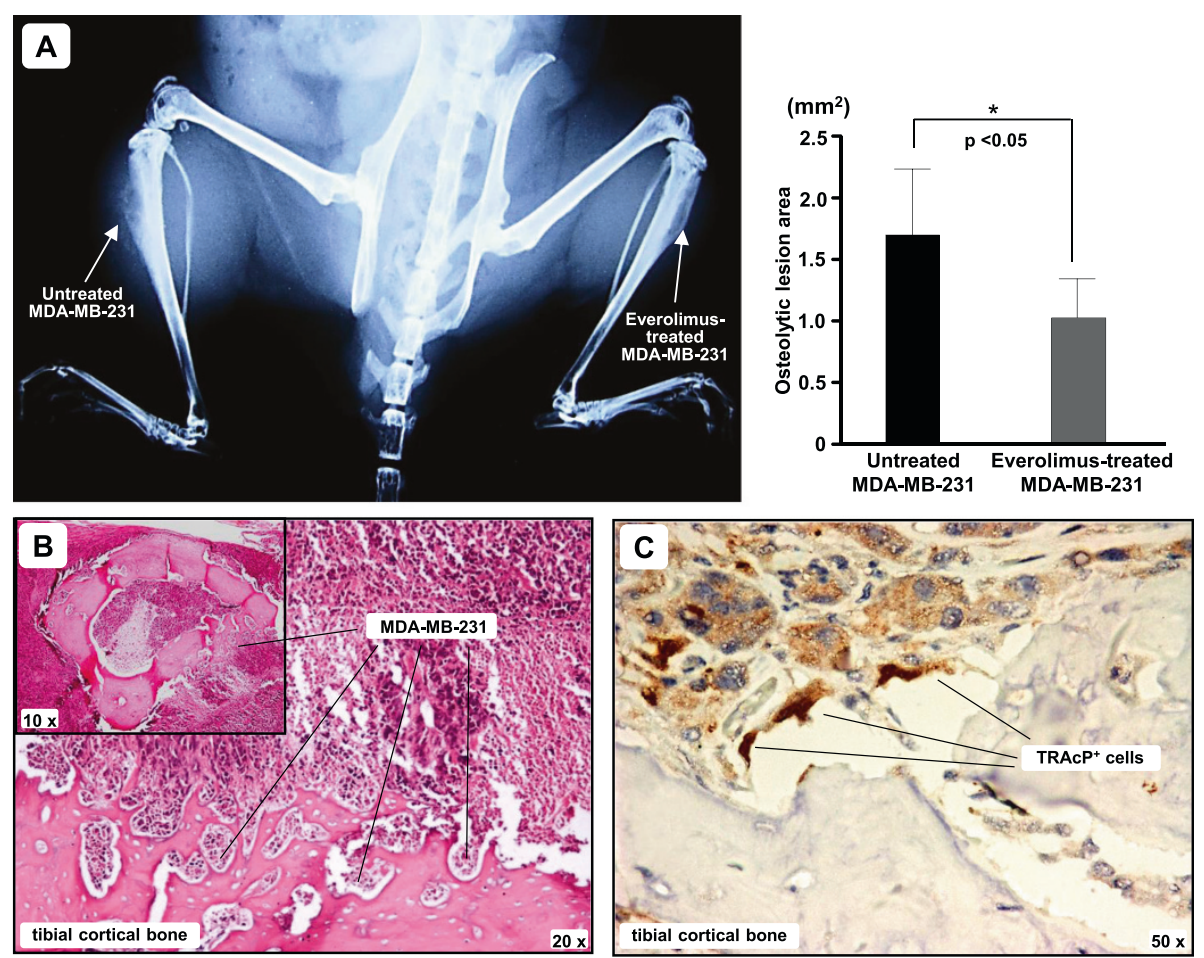

Fig. 6 Everolimus restrains the bone-metastatic potential of BC cells in vivo. Everolimus-treated and untreated MDA-MB-231 cells were intra-tibially inoculated in 8-week old SCID mice. a X-Ray image of a representative SCID mouse after 4 weeks, showing blown cortical bone of the right tibia and a smaller bone lesion produced by Everolimus-treated MDA-MB-231 cells in the left tibia. The graph shows levels of tibial erosion, measured by ImageJ software. Data are expressed as mean \pm SE of the 2D size of metastatic lesions (untreated MDA-MB-231: $1.7 \pm 0.56$ mm$^{2}$; Everolimus-treated MDA-MB-231: $\left.0.9 \pm 0.31 \mathrm{~mm}^{2} ;{ }^{*} p<0.05\right)$. b Representative image of tumor infiltration in an excised tibia $(\mathrm{H} / \mathrm{E}$ staining). The small box includes a horizontal section of the right tibia, showing that the cortical bone is largely infiltrated by MDA-MB-231 cells, as revealed at higher magnitude. $\mathbf{c}$ Detection of TRAcP ${ }^{+}$cells at the tumor/bone interface of the same tibia

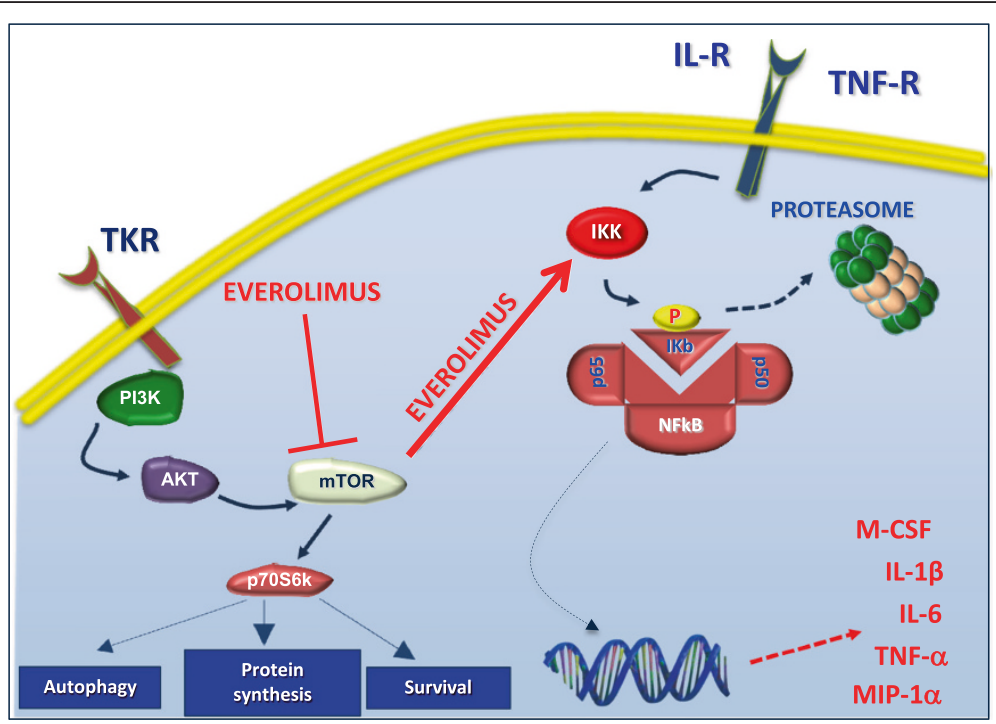

Fig. 7 Potential inhibitory interactions between the mTOR and NFkB pathways activated by Everolimus. It is suggestive that Everolimus disables IKK by p-mTOR, thus restraining the phosphorylation of IKb. This event prevents the migration of p65, as NFkB component, to the nucleus where it normally acts as transcription factor for M-CSF, TNF- $a, I L-6, I L-1 \beta$ and MIP-1a. This ultimately leads to an inhibited secretion of the pro-OC soluble mediators coded by these genes 
between these pathways. A model of interactive molecular cross-talk between mTOR and NFkB signaling is proposed in Fig. 7.

To substantiate our hypothesis, we explored the effect of mTOR inhibition on $\mathrm{BC}$ paracrine pro-OC activity in a xenograft model of bone metastatic disease. In each experiment, Everolimus-treated and untreated MDAMB-231 cells were intra-tibially injected into the left and right tibial marrow cavity, respectively, of SCID mice. This resulted in larger lytic lesions in the right than in the left tibias. This in vivo experiment supported our hypothesis that mTOR inhibition can inhibit the paracrine activity of BC cells.

Therefore, besides the general anti-tumor activity obtained by mTOR inhibition, the beneficial bone-sparing result in the BOLERO-2 trial may be explained by at least two effects. The first mechanism includes the known direct inhibition of OC activity [17, 41], while the second acts through a negative regulation of the paracrine secretion of pro-OC factors by $\mathrm{BC}$ cells. An additional $\mathrm{OC}$-independent effect is also related to the pro-osteoblast activity of Everolimus, as recently reported [50]. The definite effect of mTOR inhibition on bone metastatic cancers was recently explored in a collaborative review [51].

Finally, the potential of a sub-lethal dose of Everolimus to abrogate the paracrine pro-OC activity of $\mathrm{BC}$ cells acquires additional relevance when translated to the clinical setting. In fact, in disseminated tumor cells (DTC) PI3K/Akt signaling is reduced, thus suggesting that mTOR pathway inhibition might be linked to a biologic quiescence of DTC [52]. Thus, Everolimus at sub-lethal dose alone, or in association with other treatments, may delay or disable dormant bone metastatic disease by freezing the tumor cells living in a quiescent state in bone niches, which can generate metastases even after long periods of apparent disease remission [53].

\section{Conclusions}

Two major points emerge from an analysis of our work. The first is the capacity of Everolimus to restrain the progression of skeletal metastatic disease in $\mathrm{BC}$ patients through a specific mechanism that includes inhibiting the release by these cells of the most effective pro-OC factors such as M-CSF, TNF $\alpha$, IL-1 $\beta$, IL-6, MIP- $1 \alpha$ and MMP-13. The second point concerns the molecular pathway activated in the release of several of these factors. M-CSF, IL- $1 \beta$ and IL- 6 secretion is regulated both in OCs and BC cells by the NFkB pathway, whose signaling is apparently independent of mTOR. Instead, here we provide evidence that these pathways are interconnected and that the inhibitory effects on mTOR exerted by Everolimus include a negative regulation of NFkB, thus explaining the reduced secretion of M-CSF, IL-1 $\beta$ and IL- 6 by BC cells after mTOR inhibition. Therefore, the beneficial effects of Everolimus on bone health reported in the BOLERO-2 trial are related to the inhibition of the pro-OC paracrine activity of $\mathrm{BC}$ cells. To our knowledge, this is the first report describing this specific effect of the mTOR inhibitor.

\section{Additional file}

Additional file 1: Figure S1. Measurement of Everolimus cytotoxicity on BC cell lines. Table S1. Primer sequences used for Real-Time PCR. Table S2. Optical density (OD) values, normalized to $\beta$-actin, by Western blot analyses. (DOCX 78 kb)

\section{Abbreviations}

Akt: Protein Kinase B; BC: Breast cancer; Cat-K: Cathepsin K; C-fms: Colonystimulating factor-1 receptor; CM: Conditioned medium; EGFR: Epidermal growth factor receptor; IC: Inhibitory concentration; IGFR: Insulin growth factor receptor; InsR: Insulin receptor; IKK: IkB kinase; IL: Interleukin; MCP1: Monocyte chemoattractant protein-1; M-CSF: Macrophage-colony stimulating factor; MIP-1a: Macrophage inflammatory protein 1 alpha; MMP: Metalloproteinase; mTOR: Mammalian target of Rapamycin; NFkB: Nuclear factor kappa B; OC: Osteoclast; PBMCs: Peripheral blood mononuclear cells; PI3K: Phosphoinositide 3-kinase; PIK3CA: Catalytic subunit of PI3K; PTHrP: Parathormone-related protein; RANKL: Receptor activator of NFkB ligand; SCID: Severe combined immunodeficient; TNF: Tumor necrosis factor; TRACP: Tartrate resistant acid phosphatase.

\section{Competing interests}

All Authors declare no conflict of interest.

\section{Authors' contributions}

VS designed the study, the experiments and wrote the manuscript; SC did in vivo studies; AS carried out the molecular biology experiments; OB performed the PBMCs cultures and cell stainings; MC and MT drafted the manuscript and performed statistical analysis; GO and EM completed and analyzed histological assays; FS designed the research and wrote the paper. All Authors read and approved the manuscript.

\section{Authors' information}

VS and MC (M.D.) are attending the Postgraduate Specialization School in Oncology at the University of Bari "Aldo Moro". SC (M.D.) and AS (Ph.D.) are fellows at the Laboratory of Molecular Medicine at the Department of Biomedical Sciences and Clinical Oncology, University of Bari "Aldo Moro". MT (M.D., Ph.D.) is Assistant Professor at the Medical Oncology Unit, Department of Biomedical Sciences and Clinical Oncology, University of Bari "Aldo Moro". OB (M.D.) is postgraduate in Oncology. GO is a Ph.D. student at the Department of Pathological Anatomy, University of Bari "Aldo Moro". EM (M.D., Ph.D.) is Full Professor at the Department of Pathological Anatomy at the University of Bari "Aldo Moro". FS (M.D.) is Full Professor of Internal Medicine and Clinical Oncology and Chief of the Hospital Clinical Division of Medical Oncology, President of the Postgraduate Specialization School in Oncology and Head of the Laboratory of Molecular Medicine at the Department of Biomedical Sciences and Clinical Oncology, University of Bari "Aldo Moro".

\section{Acknowledgments}

This work was supported by AIRC (Italian Association for Cancer Research, 2012 - IG 11647) and by Italian Ministry of University and Research (PRIN 2009). The Authors are grateful to Novartis for providing Everolimus. The Authors are indebted to Dr. Marco Moschetta for his helpful contribution to X-Ray animal evaluations and to Mary Victoria Pragnell and James Michael Ashcroft for editorial assistance.

\section{Author details}

${ }^{1}$ Department of Biomedical Sciences and Human Oncology, University of Bari "A. Moro", P.zza Giulio Cesare, 11-70124 Bari, Italy. ${ }^{2}$ Department of Pathological Anatomy, University of Bari "A. Moro", Bari, Italy. 
Received: 13 November 2014 Accepted: 8 October 2015

\section{Published online: 14 October 2015}

\section{References}

1. Rosa Mendoza ES, Moreno E, Caguioa PB. Predictors of early distant metastasis in women with breast cancer. J Cancer Res Clin Oncol. 2013;139:645-52

2. Frost $A R$, Hurst DR, Shevde LA, Samant RS. The influence of the cancer microenvironment on the process of metastasis. Int J Breast Cancer. 2012;2012:756257.

3. Eilon G, Mundy GR. Direct resorption of bone by human breast cancer cells in vitro. Nature. 1978;276:726-8.

4. Guise TA, Mohammad K, Clines G, Stebbins EG, Wong DH, Higgins LS, et al, Basic mechanisms responsible for osteolytic and osteoblastic bone metastases. Clin Cancer Res. 2006:12:6213s-6s.

5. Guise TA, Yin JJ, Taylor SD, Kumagai Y, Dallas M, Boyce BF, et al. Evidence for a causal role of parathyroid hormone-related protein in the pathogenesis of human breast cancer-mediated osteolysis. J Clin Invest. 1996:98:1544-9.

6. Pederson L, Winding B, Foged NT, Spelsberg TC, Oursler MJ. Identification of breast cancer cell line-derived paracrine factors that stimulate osteoclast activity. Cancer Res. 1999:59:5849-55.

7. Freund A, Chauveau C, Brouillet JP, Lucas A, Lacroix M, Licznar A, et al. IL-8 expression and its possible relationship with estrogen-receptor-negative status of breast cancer cells. Oncogene. 2003;22:256-65.

8. Schramek D, Leibbrandt A, Sigl V, Kenner L, Pospisilik JA, Lee HJ, et al. Osteoclast differentiation factor RANKL controls development of progestin-driven mammary cancer. Nature. 2010;468:98-102.

9. Wallin JJ, Guan J, Edgar KA, Zhou W, Francis R, Torres AC, et al. Active PI3K pathway causes an invasive phenotype which can be reversed or promoted by blocking the pathway at divergent nodes. PLoS One. 2012;7:e36402.

10. Deng L, Chen J, Zhong XR, Luo T, Wang YP, Huang HF, et al. Correlation between activation of PI3K/AKT/mTOR pathway and prognosis of breast cancer in chinese women. PLoS One. 2015;10:e0120511.

11. Bachman KE, Argani P, Samuels Y, Silliman N, Ptak J, Szabo S, et al. The PIK3CA gene is mutated with high frequency in human breast cancers. Cancer Biol Ther. 2004:3:772-5.

12. Miller TW, Hennessy BT, González-Angulo AM, Fox EM, Mills GB, Chen H, et al. Hyperactivation of phosphatidylinositol-3 kinase promotes escape from hormone dependence in estrogen receptor-positive human breast cancer. J Clin Invest. 2010;120:2406-13.

13. Graham TR, Odero-Marah VA, Chung LW, Agrawal KC, Davis R, Abdel-Mageed AB. PI3K/Akt-dependent transcriptional regulation and activation of BMP-2-Smad signaling by NF-kappaB in metastatic prostate cancer cells. Prostate. 2009;69:168-80.

14. Tsubaki M, Satou T, Itoh T, Imano M, Ogaki M, Yanae M, et al. Reduction of metastasis, cell invasion, and adhesion in mouse osteosarcoma by YM529/ ONO-5920-induced blockade of the Ras/MEK/ERK and Ras/PI3K/Akt pathway. Toxicol Appl Pharmacol. 2012;259:402-10.

15. Baselga J, Campone M, Piccart M, Burris 3rd HA, Rugo HS, Sahmoud T, et al. Everolimus in postmenopausal hormone-receptor-positive advanced breast cancer. N Engl J Med. 2012;366:520-29.

16. Gnant M, Baselga J, Rugo HS, Noguchi S, Burris HA, Piccart M, et al. Effect of everolimus on bone marker levels and progressive disease in bone in BOLERO-2. J Natl Cancer Inst. 2013;105:654-63.

17. Kneissel M, Luong-Nguyen NH, Baptist M, Cortesi R, Zumstein-Mecker S. Everolimus suppresses cancellous bone loss, bone resorption and cathepsin K expression by osteoclasts. Bone. 2004;35:1144-56.

18. Maass N, Harbeck N, Mundhenke C, Lerchenmüller C, Barinoff J, Lück HJ, et al. Everolimus as treatment for breast cancer patients with bone metastases only: results of the phase II RADAR study. J Cancer Res Clin Oncol. 2013;139:2047-56.

19. Hortobagyi GN. Everolimus plus exemestane for the treatment of advanced breast cancer: A review of subanalyses from BOLERO-2. Neoplasia. 2015;17:279-88.

20. Hohensinner PJ, Kaun C, Rychli K, Niessner A, Pfaffenberger S, Rega G, et al Macrophage colony stimulating factor expression in human cardiac cells is upregulated by tumor necrosis factor-alpha via an NF-kappaB dependent mechanism. J Thromb Haemost. 2007;5:2520-8.

21. Hiscott J, Marois J, Garoufalis J, D'Addario M, Roulston A, Kwan I, et al. Characterization of a functional NF-kappa B site in the human interleukin 1 beta promoter: evidence for a positive autoregulatory loop. Mol Cell Biol. 1993;13:6231-40

22. Grove M, Plumb M. C/EBP, NF-kappa B, and c-Ets family members and transcriptional regulation of the cell-specific and inducible macrophage inflammatory protein 1 alpha immediate-early gene. Mol Cell Biol. 1993;13:5276-89.

23. Shakhov AN, Kuprash DV, Azizov MM, Jongeneel CV, Nedospasov SA Structural analysis of the rabbit TNF locus, containing the genes encoding TNF-beta (lymphotoxin) and TNF-alpha (tumor necrosis factor). Gene. 1990;95:215-21.

24. Son YH, Jeong YT, Lee KA, Choi KH, Kim SM, Rhim BY, et al. Roles of MAPK and NF-kappaB in interleukin-6 induction by lipopolysaccharide in vascular smooth muscle cells. J Cardiovasc Pharmacol. 2008;51:71-7.

25. Dan H, Cooper M, Cogswell P, Duncan J, Ting JP, Baldwin AS. Aktdependent regulation of NF-kB is controlled by mTOR and Raptor in association with IKK. Genes Dev. 2008;22:1490-00.

26. Faust J, Lacey DL, Hunt P, Burgess TL, Scully S, Van G, et al. Osteoclast markers accumulate on cells developing from human peripheral blood mononuclear precursors. J Cell Biochem. 1999;72:67-80.

27. Glantschnig H, Fisher JE, Wesolowski G, Rodan GA, Reszka AA. M-CSF, TNFalpha and RANK ligand promote osteoclast survival by signaling through mTOR/S6 kinase. Cell Death Differ. 2003;10:1165-77.

28. Lee YM, Fujikado N, Manaka H, Yasuda H, Iwakura Y. IL-1 plays an important role in the bone metabolism under physiological conditions. Int Immunol. 2010;22:805-16.

29. Scheven BA, Milne JS, Hunter I, Robins SP. Macrophage-inflammatory protein-1alpha regulates preosteoclast differentiation in vitro. Biochem Biophys Res Commun. 1999;254:773-8.

30. Pivetta E, Scapolan M, Pecolo M, Wassermann B, Abu-Rumeileh I, Balestreri $L$, et al. MMP-13 stimulates osteoclast differentiation and activation in tumour breast bone metastases. Breast Cancer Res. 2011;13:R105.

31. Engsig MT, Chen QJ, Vu TH, Pedersen AC, Therkidsen B, Lund LR, et al. Matrix metalloproteinase 9 and vascular endothelial growth factor are essential for osteoclast recruitment into developing long bones. J Cell Biol. 2000;151:879-89.

32. Lu Y, Cai Z, Xiao G, Keller ET, Mizokami A, Yao Z, et al. Monocyte chemotactic protein-1 mediates prostate cancer-induced bone resorption. Cancer Res. 2007;67:3646-53.

33. Silvestris F, Cafforio P, De Matteo M, Quatraro C, Dammacco F. Expression and function of the calcitonin receptor by myeloma cells in their osteoclastlike activity in vitro. Leuk Res. 2008;32:611-23.

34. Cafforio P, Savonarola A, Stucci S, De Matteo M, Tucci M, Brunetti AE, et al. PTHrP produced by myeloma plasma cells regulates their survival and proosteoclast activity for bone disease progression. J Bone Miner Res. 2014;29:55-66.

35. Ciavarella S, Dammacco F, De Matteo M, Loverro G, Silvestris F. Umbilical cord mesenchymal stem cells: role of regulatory genes in their differentiation to osteoblast. Stem Cells Dev. 2009;18:1211-20.

36. Kang Y, Siegel PM, Shu W, Drobnjak M, Kakonen SM, Cordón-Cardo C, et al. A multigenic program mediating breast cancer metastasis to bone. Cancer Cell. 2003;3:537-49.

37. Calvani N, Cafforio P, Silvestris F, Dammacco F. Functional osteoclast-like transformation of cultured human myeloma cell lines. Br J Haematol. 2005; 130:926-38

38. Gnant M. The role of mammalian target of rapamycin (mTOR) inhibition in the treatment of advanced breast cancer. Curr Oncol Rep. 2013;15:14-23.

39. Van Poznak C, Cross SS, Saggese M, Hudis C, Panageas KS, Norton L, et al. Expression of osteoprotegerin (OPG), TNF related apoptosis inducing ligand (TRAIL), and receptor activator of nuclear factor kappaB ligand (RANKL) in human breast tumours. J Clin Pathol. 2006;59:56-63.

40. Lau YS, Danks L, Sun SG, Fox S, Sabokbar A, Harris A, et al. RANKLdependent and RANKL-independent mechanisms of macrophage-osteoclast differentiation in breast cancer. Breast Cancer Res Treat. 2007;105:7-16.

41. Cejka D, Hayer S, Niederreiter B, Sieghart W, Fuereder T, Zwerina J, et al. Mammalian target of rapamycin signaling is crucial for joint destruction in experimental arthritis and is activated in osteoclasts from patients with rheumatoid arthritis. Arthritis Rheum. 2010;62:2294-302.

42. Rucci N, Ricevuto E, Ficorella C, Longo M, Perez M, Di Giacinto C, et al. In vivo bone metastases, osteoclastogenic ability, and phenotypic characterization of human breast cancer cells. Bone. 2004;34:697-09. 
43. Grano M, Mori G, Minielli V, Cantatore FP, Colucci S, Zallone AZ. Breast cancer cell line MDA-231 stimulates osteoclastogenesis and bone resorption in human osteoclasts. Biochem Biophys Res Commun. 2000;270:1097-00

44. Wu G, Xing M, Mambo E, Huang X, Liu J, Guo Z, et al. Somatic mutation and gain of copy number of PIK3CA in human breast cancer. Breast Cancer Res. 2005:7:R609-16.

45. Thomas RJ, Guise TA, Yin JJ, Elliott J, Horwood NJ, Martin TJ, et al. Breast cancer cells interact with osteoblasts to support osteoclast formation. Endocrinology. 1999;140:4451-8.

46. Laplante M, Sabatini DM. mTOR signaling at a glance. J Cell Sci. 2009:122:3589-94.

47. Agarwal A, Das K, Lerner N, Sathe S, Cicek M, Casey G, et al. The AKT/I kappa B kinase pathway promotes angiogenic/metastatic gene expression in colorectal cancer by activating nuclear factor-kappa B and beta-catenin. Oncogene. 2005;24:1021-31.

48. Befani CD, Vlachostergios PJ, Hatziadakl E, Patrikidou A, Bonanou S, Simos G, et al. Bortezomib represses HIF-1a protein expression and nuclear accumulation by inhibiting both PI3K/AKT/mTOR and MAPK pathways in prostate cancer cells. J Mol Med. 2012;90:45-54.

49. Hurvitz SA, Kalous O, Conklin D, Desai AJ, Dering J, Anderson L, et al. In vitro activity of the mTOR inhibitor everolimus, in a large panel of breast cancer cell lines and analysis for predictors of response. Breast Cancer Res Treat. 2015;149:669-80

50. Suvannasankha A, Chirgwin JM. Role of bone-anabolic agents in the treatment of breast cancer bone metastases. Breast Cancer Res. 2014;16:484.

51. Bertoldo F, Silvestris F, Ibrahim T, Cognetti F, Generali D, Ripamonti Cl, et al. Targeting bone metastatic cancer: Role of the mTOR pathway. Biochim Biophys Acta. 1845:2014:248-54

52. Sosa MS, Bragado P, Aguirre-Ghiso JA. Mechanisms of disseminated cancer cell dormancy: an awakening field. Nat Rev Cancer. 2014;14:611-22.

53. Balic M, Lin H, Young L, Hawes D, Giuliano A, McNamara G, et al. Most early disseminated cancer cells detected in bone marrow of breast cancer patients have a putative breast cancer stem cell phenotype. Clin Cancer Res. 2006;12:5615-21.

\section{Submit your next manuscript to BioMed Central and take full advantage of:}

- Convenient online submission

- Thorough peer review

- No space constraints or color figure charges

- Immediate publication on acceptance

- Inclusion in PubMed, CAS, Scopus and Google Scholar

- Research which is freely available for redistribution 